\title{
PENINGKATAN KETERAMPILAN BERBICARA BAHASA INGGRIS MELALUI GUIDED CONVERSATION
}

\author{
Alma Shafira' ${ }^{1}$, Doni Anggoro Ari Santoso \\ 1,2Program Studi Pendidikan Bahasa Inggris Universitas Indraprasta PGRI \\ Jalan Nangka 58 C Tanjung Barat, Jakarta Selatan, 12530, Indonesia
}

Corresponding Author(S): doni.okbi@gmail.com

\begin{abstract}
:
Penelitian ini bertujuan untuk mengetahui bagaimana peningkatan yang terjadi pada keterampilan berbicara Bahasa Inggris pada siswa dengan penggunaan metode guided conversation di kelas X AP SMK Yaspi Jaya Jakarta. Dengan mengetahui bagaimana peningkatan tersebut terjadi, diharapkan kepada calon tenaga kependidikan dapat menerapkan beberapa metode pengajaran yang menarik guna meningkatkan keterampilan berbicara Bahasa Inggris siswa. Penelitian ini merupakan studi deskriptif kualitatif dengan pendekatan penelitian tindakan kelas yang memiliki 2 siklus sebelum peneliti melakukan observasi. Pada tahap siklus 1, persentase keterampilan berbicara Bahasa Inggris siswa kelas X AP adalah 33,33\% dari 15 siswa dengan rata-rata nilai 59,3. Lalu pada siklus II peneliti menambahkan detail penjelasan dan contoh pada materi yang diajarkan, di siklus kedua ini peningkatan terjadi sebanyak $26,67 \%$ yaitu menjadi $60 \%$. Dengan demikian penggunaan metode guided conversation di kelas ini memang berhasil meningkatkan kemampuan berbicara Bahasa Inggris dengan metode-metode yang diterapkan selama hal itu menyenangkan dan mudah dipahami oleh para siswa.
\end{abstract}

Keywords:

\section{Keterampilan}

berbicara, bahasa

Inggris, Guided

Conversation

\section{PENDAHULUAN}

Bahasa merupakan salah satu alat untuk berkomunikasi. Dengan kata lain, bahasa digunakan untuk menyampaikan ide, gagasan, maksud dan tujuan atau sesuatu yang diinginkan oleh seseorang. Oleh karena itu, penggunaan bahasa sangatlah berperan penting dalam interaksi antar individu dengan individu lain. Setiap negara di dunia memiliki Bahasa sebagai identitas negara atau bahasa nasional. Namun, untuk menggeneralisasikan berbagai macam bahasa menjadi satu alat komunikasi umum, manusia di berbagai belahan dunia telah menyepakati bahwa Bahasa Inggris merupakan Bahasa internasional yang dapat digunakan untuk berkomunikasi dengan masa global. Dalam perkembangan di era globalisasi ini, pada akhirnya semua lapisan masyarakat dituntut untuk dapat berbicara dengan menggunakan Bahasa Inggris sebagai Bahasa internasional yang sudah diakui oleh dunia. Tuntutan untuk menguasai bahasa Inggris 
baik aktif maupun pasif itu sendiri yang membuat pelajaran bahasa Inggris sudah direkomendasikan sejak sekolah dasar di berbagai wilayah di Indonesia. Di sebagian banyak sekolah-sekolah di Indonesia, banyak anak-anak yang berpotensi cukup baik untuk menguasai bahasa Inggris. Tetapi faktor eksternal seperti lingkungan sosial dan faktor internal seperti motivasi yang belum berperan besar dalam merespons kebutuhan berkomunikasi membuat pelajar menjadi lamban dalam menguasai Bahasa asing, khususnya Bahasa Inggris. Maka dari itu, para guru Bahasa Inggris harus lebih peka dan tanggap kepada perkembangan kemampuan berbahasa yang mungkin dimiliki muridmurid.

Para murid di Indonesia harus Belajar bahasa Inggris sebagai salah satu dari banyaknya bahasa target. Mereka perlu belajar kedua hal penting dari Bahasa Inggris yaitu skills (keterampilan) dan juga komponen-komponen bahasanya. Dalam menguasai Bahasa Inggris, pelajar harus menguasai 4 Language skills (keterampilan berbahasa) dalam bahasa Inggris antara lain; Menyimak (listening) adalah suatu proses kegiatan mendengarkan lambing-lambang lisan yang penuh perhatian, pemahaman, apresiasi serta interpretasi untuk menangkap informasi yang disampaikan melaui ujaran lisan. Membaca (reading) adalah kegiatan meresepsi, menganalisis dan menginterpretasi yang dilakukan pembaca untuk memperoleh pesan yang hendak disampaikan oleh penulis melalui media tulisan. Berbicara (speaking) adalah sebuah kemampuan memaparkan bunyi-bunyi kata untuk mengekspresikan maupun menyampaikan pikiran, gagasan dan perasaan agar komunikan dapat mengerti pesan yang disampaikan oleh pembicara. Menulis (writing) adalah sebuah kegiatan yang dilakukan untuk mengutarakan pikiran, gagasan dan perasaan kedalam bahasa tulis. Komponen bahasa antara lain; kosa kata (vocabulary), tata bahasa (grammar), dan pengucapan (pronounciation). Maka dari itu para murid diharapkan dapat mengaplikasikan kemampuan-kemampuan dan komponen Bahasa tersebut pada aktivitas keseharian mereka.

Berhubungan dengan informasi yang telah dijelaskan di atas, salah satu keterampilan yang penting yang harus dikuasai murid adalah speaking skill (keterampilan berbicara). Keterampilan berbicara Bahasa Inggris adalah keterampilan yang paling menjanjikan yang harus dipelajari oleh para pelajar yang mana, pelajar atau murid yang tidak membiasakan diri mereka untuk berbicara bahasa Inggris akan mendapatkan banyak kesulitan ketika mereka belajar untuk berbicara Bahasa Inggris. Dengan memfokuskan keterampilan berbicara Bahasa Inggris pada siswa di era globalisasi ini seperti sekarang yang mana dibutuhkan penguasaan bahasa Inggris.

Peserta didik di Indonesia kebanyakan hanya memiliki potensi dalam keterampilan tata Bahasa Inggris (grammar), tidak dengan keterampilan berbicaranya (speaking) yang disebabkan oleh kurikulum pendidikan di Indonesia hanya berfokus pada teori. Hal inilah yang menyebabkan banyaknya murid di Indonesia tidak memiliki keterampilan berbicara Bahasa Inggris sementara mereka bisa memahami ketika ada orang asing atau guru mereka yang berbicara bahasa asing tetapi tidak bisa memberikan respons. Sehubungan dengan masalah yang telah dijabarkan di atas, peneliti melakukan observasi awal di SMK Yaspi Jaya kelas $\mathrm{X}$ untuk melihat keterampilan berbicara siswa di kelas. Peneliti menemukan bahwa keterampilan berbicara siswa SMK Yaspi Jaya kelas X masih minim karena murid yang tidak membiasakan diri mereka untuk berbicara Bahasa Inggris di sekolah. 
Dengan adanya masalah-masalah tersebut peneliti memiliki solusi untuk meningkatkan keterampilan berbicara bahasa Inggris pada siswa SMK Yaspi Jaya kelas X yaitu dengan menggunakan metode Guided Conversation. Guided Conversation sebagai salah satu bentuk strategi guru Bahasa Inggris dalam menuntun siswa untuk memperlancar keterampilan berbicara Bahasa Inggris. Dari arti kosa kata tentang Guided tersebut dapat digambarkan bahwa dalam proses pembelajaran salah satu tugas guru adalah memberikan, menuntun dan memandu siswa dengan sebaik mungkin untuk mendapatkan sesuatu yang diinginkan. Guru Bahasa Inggris Di SMK Yaspi Jaya masih menggunakan metode konvensional yang mana akan menjadi membosankan. Saat ini murid khususnya para pelajar remaja lebih tertarik berlajar melalui hal yang mereka senangi dan membuat mereka tertarik untuk mengikuti pelajaran

Siswa yang sebelumnya masih banyak belum tahu bagaimana mengucapkan sebuah kata dalam Bahasa Inggris (misalnya, mengucapkan book) yang terkadang dibaca oleh siswa dengan bo-ok. Dengan tuntunan guru maka dari bo-ok menjadi (bok) dan banyak lagi kosa kata atau kalimat yang sulit dikatakan oleh siswa karena siswa terbiasa dengan Bahasa ibu atau bahasa Indonesia dan Bahasa daerah.

Dengan demikian, Guided Conversation memberikan inspirasi kepada siswa untuk menciptakan suasana komunikatif dalam memberikan ide, pemikiran dan tanggapan sekaligus memberikan kritikan dalam membetulkan perbincangan. Guided Conversation juga merupakan sebuah desain yang tepat guna untuk membantu siswa mendapatkan teknik belajar cepat dan tepat sehingga dapat menguasai materi Bahasa Inggris sekaligus mampu mewujudkan keterampilan berbicara. Kaitan lain yang berhubungan dengan Guided Conversation ialah membimbing siswa bagaimana bertanya dan menjawab yang baik dan benar menurut tata cara berbicara bahasa Inggris disertai dengan tuntunan yang mendekati gaya bicara Bahasa native speaker.

Peneliti menyertakan 3 alasan pemilihan judul yaitu Peningkatan Keterampilan Berbicara Bahasa Inggris Melalui Guided Conversation. Pertama, peneliti sadar bahwa keterampilan berbicara Bahasa Inggris adalah hal penting yang harus dikuasai para murid di Indonesia karena Bahasa Inggris adalah bahasa Internasional yang digunakan di seluruh penjuru dunia, jadi dengan menguasai keterampilan berbicara yang baik dan benar akan memberikan keuntungan yang sangat besar untuk mereka. Kedua, para murid di Indonesia memiliki kesulitan untuk berbicara Bahasa Inggris dengan baik dan benar karena mereka tidak pernah mencoba membiasakan diri mereka untuk berbicara bahasa Inggris di kehidupan sehari-hari ataupun di sekolah. Di SMK Yaspi Jaya kelas X siswa harus diberikan kesempatan lebih untuk menunjukkan kemampuan mereka berbicara dengan Bahasa Inggris. Ketiga, kebanyakan guru-guru Bahasa Inggris yang ada di Indonesia masih menggunakan metode lama dengan hanya mengajarkan teorinya saja kepada para murid yang mana sudah menjadi hal yang membosankan untuk para murid jika hanya belajar dengan teori. Sementara belajar Bahasa Inggris harus diimbangi juga dengan praktik berbicaranya di SMK Yaspi Jaya.

Penulis mengacu pada sebuah penelitian guna untuk mendukung masalah yang sedang dibahas agar membantu melengkapi penelitian ini. Kajian dari hasil penelitian ini gunakan untuk membandingkan penelitian yang telah dilakukan sebelumnya dengan penelitian yang sedang dilakukan sekarang sehingga dapat dilihat hasil dari posisi penelitian ini. 
Penelitian yang pertama yang dilakukan oleh Elisabet Ayu Kartini yang diterbitkan pada tahun 2017 dengan judul "Teknik Make A Match dan Keterampilan Berbicara Bahasa Inggris Siswa Kelas X SMK PGRI 16." Tujuan dari penelitian ini adalah untuk mengetahui bagaimana penggunaan Teknik Make A Match dalam meningkatkan keterampilan berbicara bahasa Inggris siswa kelas X SMK PGRI 16. Kesimpulan hasil penelitian ini menunjukkan adanya keberhasilan dari penelitian ini dengan adanya peningkatan keaktifan siswa di kelas dan meningkatkan keterampilan berbicara bahasa Inggris siswa kelas $\mathrm{X}$ dengan persentase kenaikan sebesar 60,70\%. Adapun perbedaan dan persamaan dengan penelitian yang sedang dilakukan penulis yakni penelitian yang dilakukan yaitu peningkatan keterampilan berbicara bahasa Inggris siswa dengan menggunakan teknik guided conversation. Persamaan dalam penelitian ini dengan penelitian yang dilakukan penulis yakni pada peningkatan keterampilan berbicaranya.

Peneliti juga mengacu pada penelitian kedua yang dilakukan oleh Afifah Azzarah yang diterbitkan pada tahun 2017 dengan judul "Pengaruh Penggunaan Media Lagu Terhadap Keterampilan Berbicara Bahasa Inggris Siswa Kelas XI SMK Amaliah". Tujuan dari penelitian ini adalah untuk mengetahui pengaruh penggunaan media lagu terhadap keterampilan berbicara bahasa Inggris siswa SMK. Hasil penelitian menunjukkan bahwa ada pengaruh yang signifikan dalam meningkatkan motivasi siswa dengan menggunakan media lagu pada siswa SMK Amanilah. Adapun persamaan dan perbedaan dalam penelitian ini yaitu dalam peningkatan keterampilan berbicaranya, perbedaan dalam penelitian ini yaitu dalam penggunaan lagu sebagai media utamanya, sedangkan peneliti menggunakan teknik guided conversation dalam meningkatkan keterampilan berbicara siswa.

Berdasarkan alasan yang telah dikemukakan, bahwa teknik peningkatan keterampilan berbicara bahasa Inggris melalui Guided Conversation adalah cara terbaik untuk memecahkan masalah dan juga akan membuat kelas bahasa Inggris menjadi tidak membosankan. Khususnya di SMK Yaspi Jaya Kelas X. Penelitian ini bertujuan untuk meningkatkan keterampilan berbicara Bahasa Inggris melalui guided conversation pada siswa kelas X SMK Yaspi Jaya Jakarta.

\section{METODE}

Jenis penelitian ini adalah penelitian kualitatif, yaitu penelitian yang memiliki tujuan menjelaskan suatu fenomena secara objektif. Penelitian kualitatif merupakan penelitian yang menghasilkan kata-kata tertulis atau lisan dari orang-orang dan perilaku yang dapat diamati.

Penelitian yang ingin dilakukan merupakan penelitian tindakan. Penelitian tindakan merupakan intervensi dunia nyata yang ditujukan untuk meningkatkan diskusi praktis. Zunaida (2009: 46) menyetujui penelitian tindakan yang dilakukan oleh guru untuk meningkatkan pemikiran pembelajaran yang menjadi tanggung jawab dan disebut "Penelitian Tindakan Kelas".

Teknik penelitian yang digunakan adalah kepustakaan, penelitian lapangan, acting, dan observasi. Fokus dalam penelitian ini adalah peningkatan keterampilan berbicara bahasa Inggris melalui guided conversation di sekolah SMK Yaspi Jaya Jakarta, sedangkan subfokus siswa kelas X SMK Yaspi Jaya dengan jumlah 30 siswa. Instrumen penelitian 
meliputi peneliti itu sendiri, wawancara, observasi, dan dokumentasi. Teknik pemeriksaan keabsahan data menggunakan triangulasi metode.

\section{HASIL DAN PEMBAHASAN \\ Hasil}

Peneliti mengambil data wawancara, catatan lapangan, dan hasil tes berdasarkan triangulasi data. Penjelasan dari masing-masing bagian adalah sebagai berikut:

\section{Hasil Wawancara}

Peneliti menemui guru Bahasa Inggris untuk menyampaikan rencana penelitian yang telah mendapat izin dari kepala sekolah. Dalam penelitian tersebut peneliti memberitahukan metode yang digunakan dalam penelitian, yaitu menggunakan metode guided conversation. Dalam pertemuan tersebut peneliti juga berdiskusi dengan guru Bahasa Inggris siswa kelas X mengenai jumlah siswa, kondisi kelas, peminatan siswa, seberapa pentingnya Bahasa Inggris bagi guru dan siswa, dan bagaimana sikap siswa sewaktu belajar Bahasa Inggris di kelas.

Berdasarkan data yang diperoleh dari guru kelas X, jumlah siswa kelas X AP sebanyak 18 siswa. Pada kelas X AP, dari pandangan guru Bahasa Inggris yaitu ibu Suryanti, S.Pd, berpendapat bahwa siswa merasa percaya diri dan senang saat pelajaran Bahasa Inggris khususnya saat speaking berlangsung, tetapi seperti kondisi kelas pada umumnya, siswa masih sangat kurang dalam kemampuan kosakata dan pengucapannya sehingga sulit bagi mereka untuk merangkai kalimat saat speaking. Kemudian kendala yang dihadapi guru karena kurangnya kemampuan siswa dalam pengucapan dan kosakata untuk berbicara Bahasa Inggris bagi siswa kelas X SMK Yaspi Jaya Jakarta. Metode yang sering digunakan guru dalam mengajar Bahasa Inggris adalah mengaplikasikan grammar pada speaking skill dan juga metode speech atau pidato. Guru juga terkadang menggunakan proyektor atau gambar-gambar dari buku sebagai instrumen pengajaran.

Siswa kelas X SMK Yaspi Jaya cukup berminat terhadap kelas Bahasa Inggris khususnya saat kelas speaking. Beberapa siswa berpendapat bahwa kelas speaking menyenangkan. Siswa juga berpendapat bahwa keempat skill Bahasa Inggris yang dipelajari, listening adalah skill yang tersulit bagi mereka. Pemahaman siswa saat guru berbicara Bahasa Inggris cukup bagus tetapi mereka tidak bisa merespons saat guru bertanya dengan menggunakan Bahasa Inggris. Bagi guru dan siswa Bahasa Inggris sangatlah penting khususnya speaking skill terlebih mereka adalah siswa administrasi perkantoran yang sebagian besar di tuntut untuk bisa berbicara Bahasa Inggris di dunia kerjanya nanti.

Berdasarkan hasil wawancara yang didapat dari guru dan siswa-siswa kelas X SMK Yaspi Jaya, peneliti menyimpulkan bahwa peminatan dan kepercayaan diri siswa kelas X SMK Yaspi Jaya pada Bahasa Inggris khususnya speaking cukup baik, namun dengan masalah keterbatasan kosakata yang mereka miliki menjadikan mereka sulit untuk merangkai kata-kata saat berbicara Bahasa Inggris. Media yang digunakan oleh guru saat mengajar pun cukup memadai yaitu menggunakan projector sebagai media yang digunakan agar siswa lebih mudah untuk mempelajari materi. Hanya saja kendala mereka terhadap keterbatasan kosakata dan pengucapan untuk merangkai kalimat masih sangat rendah. Maka dari itu peneliti memiliki solusi dengan menggunakan metode guided conversation sebagai metode yang diharapkan dapat meningkatkan keterampilan berbicara Bahasa Inggris pada siswa kelas X SMK Yaspi Jaya Jakarta. 


\section{Laporan Observasi}

Dalam observasi peneliti melakukan "partisipatif observasi". Dalam hal ini, peneliti yang mengamati proses pembelajaran yang dilakukan guru di kelas. Peneliti melaporkan proses pembelajaran yang dilaksanakan oleh guru kelas, dan mencari apa yang menjadi penyebab kesulitan siswa dalam mempelajari Bahasa Inggris khususnya keterampilan berbicara.

Pada saat proses pembelajaran, guru menjelaskan materi pada siswa dengan menggunakan Bahasa Indonesia maka siswa tidak terbiasa mendengarkan guru berbicara dalam Bahasa Inggris selama proses pembelajaran karena siswa lebih mengerti saat guru menjelaskan materi dengan Bahasa Indonesia. Hal itu yang membuat siswa kurangnya dalam penguasaan kosakata sehingga siswa tidak dapat membuat kalimat dalam Bahasa Inggris dengan baik dan benar. Kurangnya dalam penguasaan kosakata juga berpengaruh pada siswa dalam keterampilan berbicara Bahasa Inggris. Siswa tidak terbiasa menggunakan Bahasa Inggris selama pembelajaran di dalam kelas, ketika belajar siswa lebih sering menggunakan Bahasa Indonesia agar lebih dapat dipahami dengan baik.

1. Prosedur Siklus

Untuk mengetahui bagaimana peneliti memperoleh hasil tes, di bawah ini prosedur setiap siklus sebagai berikut:

a. Siklus I

Pelaksanaan penelitian tindakan kelas pada siklus I dilaksanakan pada tanggal 4 Mei 2020 dengan metode guided conversation. Sajian siklus terdiri dari perencanaan, pelaksanaan, pengamatan dan refleksi.

1) Perencanaan

Pada tahap perencanaan tindakan siklus I, kegiatan yang dilakukan yaitu menyusun rencana pelaksanaan pembelajaran (RPP) yang terdiri dari dua kali pertemuan. RPP yang telah disusun dikonsultasikan kepada guru Bahasa Inggris kelas $\mathrm{X}$ agar dapat disesuaikan dengan situasi dan kondisi di sekolah. RPP yang telah disepakati digunakan sebagai acuan guru dan peneliti dalam melaksanakan pembelajaran dengan menggunakan metode guided conversation. Peneliti menyiapkan bahan ajar dalam pembelajaran di kelas. Menyusun lembar observasi siswa yang digunakan sebagai pedoman pengamatan kegiatan siswa selama pembelajaran berlangsung.

2) Pelaksanaan Kegiatan

Peneliti membagi pelaksanaan kegiatan menjadi dua kali pertemuan. Pertemuan pertama diisi dengan menyampaikan materi dan pertemuan kedua diisi dengan menguji murid dengan memberikan tes terkait materi yang telah diberikan.

Pada kegiatan awal di pertemuan pertama, peneliti memasuki ruang kelas X. Guru memberitahukan siswa bahwa peneliti akan mengambil alih kelas selama beberapa kali pertemuan ke depan sebagai guru pengganti sementara di kelas X. Peneliti memberi salam dan menyapa para siswa dengan ucapan "good morning students" siswa menjawab salam guru dengan mengucapkan "good morning miss".

Kemudian peneliti bertanya apakah siswa suka menggunakan Bahasa Inggris saat berkomunikasi di rumah bersama keluarga. Apakah mereka pernah mencoba untuk menggunakan Bahasa Inggris untuk berkomunikasi dengan 
keluarga atau teman. Seluruh siswa menjawab tidak pernah menggunakan Bahasa Inggris untuk berkomunikasi dengan keluarga atau teman.

Selanjutnya peneliti memberikan materi tentang descriptive text kepada siswa. Materi tersebut yang akan digunakan untuk mengetes siswa pada pertemuan selanjutnya. Peneliti memberikan penjelasan tentang descriptive text beserta contohnya hingga siswa mengerti dan dapat mengaplikasikannya. Peneliti juga meminta beberapa siswa memberikan contoh terkait materi yang telah dibahas.

Pada kegiatan penutup, peneliti memberikan kesempatan pada siswa untuk bertanya mengenai materi yang sudah diberikan oleh peneliti. Selanjutnya, peneliti menutup pelajaran dengan salam dan tidak lupa memberikan motivasi kepada siswa untuk belajar dengan giat.

Pada pertemuan kedua, peneliti menjelaskan apa yang akan peneliti lakukan yaitu pertama-tama peneliti akan memberikan tugas untuk mendeskripsikan gambar yang telah diberikan oleh peneliti dan berdiskusi dengan teman sebangku. Selanjutnya, peneliti meminta siswa secara bergantian mendeskripsikan gambar dengan teman sebangkunya dalam Bahasa Inggris.

3) Pengamatan

Pada tahap ini peneliti mencoba untuk mengevaluasi semua kegiatan selama mengajar di dalam kelas. Tentang kinerja peneliti, situasi kelas, dan respons siswa. Terkait dengan kinerja peneliti, peneliti telah menyelesaikan tugas sesuai dengan rencana pelajaran yang telah dibuat. Peneliti membuat catatan lapangan tentang kondisi ruang kelas. Ada beberapa siswa yang aktif menjawab pertanyaan peneliti dengan benar terkait dengan materi yang telah diberikan dan ada puka beberapa siswa yang tidak tertarik karena alasan memang tidak suka pelajaran Bahasa Inggris atau tidak memahami materi yang telah diberikan. Oleh karena itu sebagian besar siswa masih kurang fasih berbicara Bahasa Inggris.

Selain itu pertemuan kedua adalah akhir dari siklus I, peneliti mempersiapkan tes untuk mengevaluasi siswa dalam siklus I. Peneliti memberikan gambar pada siswa untuk dideskripsikan. Pada saat peneliti melakukan penelitian dari 18 siswa ada 3 siswa yang tidak hadir. Hasil dari siklus I, ada 10 siswa yang mendapatkan skor rendah dan ada 5 siswa yang mencapai KKM. Rata-rata data pada siklus I adalah 59,33. Dapat disimpulkan bahwa 33,33\% dari siswa telah mencapai KKM.

4) Refleksi

Refleksi merupakan suatu langkah untuk menilai kembali mengenai tindakan yang telah dilakukan selama siklus I, berikut hasil refleksi pada siklus I. Kemudian. Peneliti mencoba untuk mengevaluasi tindakan agar tahu bagaimana prestasi siswa dengan menggunakan metode guided conversation ini di dalam kelas. Setelah dievaluasi, peneliti mencoba untuk mengubah aspek yang kurang dalam pembelajaran. Dalam penelitian siswa masih malu dan tidak percaya diri untuk berbicara di depan kelas dikarenakan kurang menguasai kosakata Bahasa Inggris. Pengucapan yang salah ketika berbicara Bahasa Inggris dikarenakan kurangnya kosakata yang menyebabkan sulitnya 
b. Siklus II

berbicara Bahasa Inggris yang akhirnya siswa cenderung tidak semangat dalam pembelajaran Bahasa Inggris.

Siklus II harus dilakukan karena pada siklus pertama nilai rata-rata siswa belum mencapai target yang peneliti buat yaitu 60\% siswa mencapai nilai KKM. Ratarata nilai yang didapat dari hasil siklus I yaitu 59,3 yang berarti hanya 33,3\% siswa yang berhasil mencapai KKM.

Pada siklus pertama, siswa ada yang mengaku hanya mengingat dan hafal 2 buah kosakata baru selama belajar tentang descriptive text ini, ada juga yang hanya mengingat dan hafal 5 sampai 8 kosakata baru.

Pada tes siklus 1, peneliti meminta siswa untuk mendeskripsikan orang yang ada disekitar mereka, seperti teman, guru dan keluarga, tetapi peneliti tidak mengizinkan jika satu kelas hanya mendeskripsikan tentang tamannya saja, harus berbeda-beda dan bervariasi. Lalu para siswa bingung dan kewalahan dalam mendeskripsikannya karena keterbatasan kosakata yang mereka miliki.

Pada siklus kedua ini peneliti meningkatkan penjelasan agar lebih mendetail dan lebih mudah dipahami oleh para siswa. Peneliti meningkatkan penjelasan dengan menggunakan media yaitu contoh video descriptive text dalam Bahasa Inggris agar siswa lebih semangat dan tidak merasa bosan pada saat proses pembelajaran di kelas dan juga mendapatkan banyak kosakata baru dari video yang diputarkan serta mendapatkan contoh bagaimana cara pengucapan dalam Bahasa Inggris dengan baik dan benar.

Kemudian, peneliti juga mengubah tes yang akan dilakukan pada siswa. Jika pada siklus I siswa diminta untuk mendeskripsikan orang yang ada di sekitar mereka dan tidak boleh sama satu sama lain maka di siklus II ini peneliti hanya menentukan satu tema yaitu mendeskripsikan tentang teman sebangkunya saja, jadi para siswa hanya fokus pada satu objek saja agar para siswa lebih mudah menjalani tes yang diberikan peneliti.

1. Perencanaan

Pada fase siklus kedua, peneliti merevisi RPP yang tidak tepat pada siklus pertama. Oleh karena itu, peneliti menyiapkan materi yang lebih detail tentang penggunaan metode guided conversation di dalam kelas dan instrumen untuk tes di akhir siklus kedua. Selanjutnya, peneliti menyiapkan catatan lapangan untuk mengamati sementara proses belajar mengajar yang dilaksanakan di kelas.

2. Pelaksanaan Kegiatan

Tindakan siklus kedua untuk pertemuan pertama dilakukan pada tanggal 11

Mei 2020. Peneliti memberi pertanyaan pembuka untuk mengingatkan tentang materi yang siswa telah pelajari di pertemuan sebelumnya. Setelah beberapa siswa menjawab pertanyaan dengan menjelaskan singkat tentang materi sebelumnya, peneliti mulai menjelaskan lebih detail. Seperti cara mendeskripsikan dengan pengucapan Bahasa Inggris yang baik dan benar. Oleh karena itu, peneliti memberikan beberapa contoh lain. Peneliti mengarahkan siswa untuk lebih aktif dalam pembelajaran speaking di kelas. 
Pada siklus kedua ini peneliti meningkatkan penjelasan agar lebih mendetail dan lebih mudah dipahami oleh para siswa.

Pada kegiatan penutup peneliti bertanya kepada siswa apakah ada yang masih kurang dipahami dari materi yang telah diberikan. Lalu peneliti meminta satu murid untuk menjelaskan uraian singkat tentang materi yang telah dijelaskan. Setelah dirasa cukup dan peneliti berfikir bahwa siswa sudah cukup paham, peneliti menutup kegiatan dengan memberi salam pada siswa.

Pada pertemuan kedua di siklus kedua, peneliti memutarkan video berbahasa Inggris tentang descriptive text di depan kelas dengan menggunakan projector. Pada saat pemutaran video selesai, peneliti memutar ulang video kembali dengan tujuan untuk membantu para siswa dalam memberi tahu arti dari kosakata yang mungkin masih terdengar asing bagi mereka dengan cara mem-pause video dan mengartikan kata demi kata agar siswa lebih mudah memahami dan mendapatkan banyak kosakata baru dengan mudah.

Dengan cara ini peneliti merasakan peningkatan yang efisien pada para siswa. Para siswa dirasa lebih memperhatikan dan memahami apa yang peneliti arahkan dan jelaskan. Siswa yang sebelumnya tidak tertarik jadi lebih memperhatikan, dan siswa yang sudah tertarik dari awal terlihat lebih memahami konteks terkait.

Lalu, setelah video diputarkan, peneliti kembali meminta siswa satu persatu maju ke depan kelas untuk mendeskripsikan teman sebangkunya agar siswa lebih mudah menjalani tes yang diberikan peneliti dan lebih fokus dengan hanya mendeskripsikan teman yang sudah dikenalnya. Lalu peneliti mengambil data nilai para siswa.

3. Pengamatan

Pada fase siklus kedua ini, peneliti mencoba untuk mengevaluasi semua kegiatan selama proses mengajar ada beberapa siswa yang aktif menjawab pertanyaan peneliti dengan benar dan ada beberapa siswa yang tidak tertarik karena masih bingung bagaimana mengucapkan kalimat Bahasa Inggris dengan baik dan benar. Oleh karena itu, peneliti memberi contoh kembali pada siswa agar lebih mengerti.

Pada fase siklus kedua ini ada peningkatan yang terlihat pada siswa, dari beberapa siswa yang sebelumnya tidak aktif dalam menjawab pertanyaan dalam Bahasa Inggris dalam siklus kedua ini siswa lebih berani menjawab beberapa pertanyaan tentang materi yang diberikan dalam Bahasa Inggris. Siswa lebih percaya diri dan aktif dalam berbicara Bahasa Inggris dengan guru ataupun teman.

Selain itu pertemuan kedua pada tanggal 14 Mei 2020 adalah akhir dari siklus II. Peneliti mempersiapkan tes untuk evaluasi siswa dalam siklus II. Peneliti memberikan gambar lalu peneliti meminta siswa untuk mendeskripsikan gambar yang telah disiapkan peneliti. Peneliti mengambil sample yang sama yaitu 15 siswa seperti saat siklus pertama. Hasil dari siklus II ada 6 siswa yang mendapatkan skor rendah dan ada 9 siswa yang mencapai KKM. Rata-rata 
nilai pada siklus II adalah 76,67. Dapat di simpulkan bahwa $60 \%$ dari siswa telah mencapai KKM

4. Refleksi

Dalam tahap kedua ini, peneliti kembali mengevaluasi seluruh tindakan yang telah dilakukan selama siklus I dan II. Kemudian, peneliti mengevaluasi dan meningkatkan penggunaan metode guided conversation di kelas untuk memotivasi siswa dalam proses pembelajaran. Dalam penelitian ini, terdapat perubahan yang signifikan pada keaktifan siswa dalam mempelajari materi yang disampaikan.

Berdasarkan hasil penelitian, dapat disimpulkan bahwa penggunaan metode guided conversation dalam pengajaran di kelas X itu tepat. Metode ini dapat memotivasi siswa untuk menjadi lebih aktif dalam belajar Bahasa Inggris khususnya keterampilan berbicara. Peningkatan aktivitas ini diikuti dengan peningkatan nilai siswa yang cukup signifikan.

\section{Pembahasan}

Di sini peneliti ingin menginterpretasikan hasil dari wawancara, laporan observasi, dan tes. Berdasarkan hasil wawancara dengan guru Bahasa Inggris di SMK Yaspi Jaya dan disimpulkan ada beberapa faktor yang mempengaruhi keterampilan berbicara Bahasa Inggris kelas X AP yaitu para siswa masih memiliki beberapa kesulitan dalam berbicara bahasa Inggris, karena siswa kurang menguasai kosakata. Oleh karena itu, siswa harus memahami kosakata Bahasa Inggris.

Sebenarnya minat siswa kelas X AP terhadap mata pelajaran Bahasa Inggris cukup baik, namun karena penggunaan metode dan media yang digunakan oleh guru membuat kurangnya minat terhadap mata pelajaran Bahasa Inggris juga bisa menjadi salah satu faktor. Metode dan instrument yang digunakan guru juga masih terbilang tradisional yang mungkin membuat siswa kurang berminat pada kelas Bahasa Inggris.

Siswa kesulitan berbicara Bahasa Inggris karena kurangnya penguasaan kosakatanya dan juga kurangnya penguasaan tata Bahasa Inggris yang membuat siswa kesulitan merangkai kata-kata saat berbicara Bahasa Inggris. Beberapa siswa berfikir bahwa penguasaan speaking penting guna menunjang karier mereka di bidang administrasi perkantoran, tetapi karena sulitnya menguasai skills Bahasa Inggris terutama kelemahan mereka adalah terbatasnya kosakata membuat motivasi mereka berkurang untuk meningkatkan keterampilan berbicara Bahasa Inggris mereka. Terkait dengan keterampilan berbicara, keterampilan berbicara siswa kelas X AP adalah di bawah rata-rata mengingat kelemahan terbesar mereka adalah listening dan terbatasnya vocabulary.

Berdasarkan hasil observasi, kurangnya variasi dalam menggunakan metode atau media pembelajaran sangat kurang untuk memotivasi siswa dalam belajar. Hal ini dapat terlihat dari ketakutan siswa ketika diminta untuk berbicara dengan Bahasa Inggris di kelas. Kurangnya penguasaan kosakata Bahasa Inggris pada siswa yang menjadi salah satu penyebab kesulitan siswa dalam berbicara Bahasa Inggris. Dalam hal ini, kemampuan guru dalam menggunakan metode dan media pembelajaran yang menarik untuk memotivasi siswa agar berani berbicara di kelas sangatlah dibutuhkan. Penggunaan metode dan media belajar yang tepat akan membuat siswa lebih berani, termotivasi, dan 
nyaman dalam belajar. Semua hal tersebut akan berpengaruh terhadap hasil belajar yang diperoleh siswa.

Selanjutnya, peneliti ingin menafsirkan hasil tes. Peneliti telah melaksanakan penelitian tindakan kelas yang terdiri dari dua siklus. Siklus I terdiri dari 2 pertemuan. Pertemuan pertama menjelaskan tentang bahan materi dan memberikan latihan atau soal. Pertemuan kedua membuat tugas pada siswa untuk maju ke depan kelas berbicara Bahasa Inggris untuk mendeskripsikan teman sebangkunya. Pertemuan kedua membuat tugas untuk siswa untuk mendeskripsikan gambar yang telah diberikan. Hasil dari siklus I, ada 15 siswa yang mengambil evaluasi, 10 siswa mendapatkan nilai rendah dan 5 orang siswa mencapai KKM. Nilai tertinggi adalah 75 dan nilai terendah pada siklus I adalah 50. Ratarata nilai pada siklus I adalah 59,33. Dapat disimpulkan bahwa hanya 33,33\% dari siswa yang telah mencapai KKM.

Setelah itu, peneliti melakukan siklus kedua, yang terdiri dua pertemuan, pertemuan pertama menjelaskan tentang materi dan rincian lebih lanjut tentang pengucapan kosakata Bahasa Inggris yang baik dan benar dengan tema yang telah diberikan oleh peneliti. Pertemuan kedua memberikan tes untuk evaluasi dengan hanya menggunakan satu tokoh yang untuk di deskripsikan yaitu teman sekelas untuk dideskripsikan para siswa. Dari 15 siswa, ada 9 siswa yang mencapai KKM dan 6 siswa masih mendapatkan nilai rendah. Nilai terendah adalah 55 dan nilai tertinggi adalah 85. Rata-rata nilai pada siklus 2 adalah 74,67. Dapat disimpulkan bahwa $60 \%$ siswa telah mencapai KKM.

Kesimpulan ada $26,67 \%$ peningkatan KKM dari siklus I ke siklus II peneliti menyimpulkan bahwa penggunaan metode guided conversation di kelas tepat dan dapat digunakan untuk pembelajaran berbicara Bahasa Inggris di kelas X SMK Yaspi Jaya. Penggunaan metode guided conversation dapat meningkatkan nilai siswa karena penggunaan metode guided conversation siswa lebih semangat dalam mengikuti pelajaran yang membuat mereka lebih fokus dan mudah mengerti materi yang disampaikan.

Penggunaan metode guided conversation di kelas juga dapat menciptakan suasana kelas yang baru dan lebih menghidupkan suasana belajar juga membuat siswa ingin belajar Bahasa Inggris lebih lama lagi. Dengan menggunakan metode guided conversation ini guru juga dapat langsung melakukan praktik speaking sehingga siswa dapat langsung mendengarkan guru berbicara dalam Bahasa Inggris dan siswa juga langsung mendapat contoh pronunciation yang baik yang benar. Dengan begitu peneliti dapat menyimpulkan bahwa penggunaan metode guided conversation di dalam kelas sangat banyak manfaatnya dan sangat efisien baik bagi guru dan bagi para siswa.

\section{Simpulan}

Berdasarkan hasil penelitian dan pembahasan dapat menyimpulkan beberapa hal dari hasil penelitian penerapan penggunaan metode guided conversation adalah sebagai berikut:

1. Penggunaan metode guided conversation di kelas dapat membantu siswa dalam meningkatkan keterampilan berbicara menjadi lebih aktif dan tidak malu lagi untuk maju ke depan kelas. 
2. Pembelajaran dengan menggunakan metode guided conversation dapat meningkatkan motivasi belajar siswa di kelas. Susana di kelas menjadi lebih hidup dan beberapa siswa yang pasif menjadi lebih aktif di kelas X SMK Yaspi Jaya.

3. Pembelajaran dengan menggunakan metode guided conversation di dalam kelas menghasilkan nilai belajar siswa dengan hasil tes dari siklus I sebesar 33,33\% dengan nilai rata-rata 59,3.

4. Pada siklus II masih dengan metode yang sama, peneliti menambahkan detail penjelasan beserta contoh materi kepada siswa, contoh materi berupa video contoh percakapan dalam Bahasa Inggris. Dalam revisi di siklus II ini mendapatkan peningkatan hasil belajar siswa dengan persentase sebesar $26,67 \%$ yang mana pada siklus dua murid menghasilkan rata-rata nilai sebesar 74,67 dengan persentase sebesar $60 \%$.

5. Melalui metode dan teknik dalam pembelajaran penggunaan metode guided conversation ini terbukti mendapat peningkatan keterampilan berbicara Bahasa Inggris yang signifikan.

6. Penggunaan metode guided conversation di dalam kelas dapat meningkatkan motivasi belajar siswa karena kondisi kelas yang baru dan tidak membosankan.

7. Penggunaan metode guided conversation di dalam kelas juga dapat meningkatkan kelemahan siswa X AP yaitu dalam keterbatasan kosakata. Dengan penggunaan metode guided conversation, siswa akan mendapat banyak kosakata Bahasa Inggris yang baru dan juga cara pengucapan yang baik dan benar.

8. Keterampilan berbicara siswa kelas X AP juga meningkat dengan penggunaan metode guided conversation di dalam kelas. Dengan mendapatkan kosakata baru dapat menjadikan siswa lebih percaya diri untuk maju dan berbicara Bahasa Inggris di depan kelas.

9. Hal yang membuat siswa kelas X AP kesulitan berbicara Bahasa Inggris juga dapat diatasi dengan penggunaan metode guided conversation di dalam kelas yang membuat mereka lebih semangat berbicara dan belajar Bahasa Inggris.

10. Penggunaan Bahasa Inggris di dalam kelas juga bisa menjadi motivasi para siswa untuk mengikuti pelajaran Bahasa Inggris dengan semangat, karena mereka tidak merasa bosan dan tidak merasa sedang belajar atau harus menghafal teori-teori yang berat seperti kelas Bahasa Inggris pada biasanya.

\section{REFERENSI}

Syamsuddin, A. (2003). Peran guru membimbing keberhasilan siswa. Bandung: Sinar Baru.

Arikunto, E. (2004). Komunikasi massa suatu pengantar. Bandung: Simbosa Rekatama Media

Chapelle, A. C. (2004). English language learning and technology. London; Benjamins Publishing Company.

Dardjowidjojo, S. (2003). Psikolinguistik pengantar pemahaman bahasa manusia. Jakarta: Balai Pustaka.

Douglas, H. B. (2001). Teaching by principle and interactive approach to language pedagogy. San Fransisco: Longman.

Hakim, T. (2009). Mengatasi kegalalan dalam berbicara bahasa Inggris. Jakarta: Puspa Swara.

Hamalik. (2003). Peranan motivasi terhadap keberhasilan dalam belajar. Bandung: Angkasa. 
Hamer, J. (2009). The practice of english language teaching. Boston: Pearson.

H. Nashar. (2004). Motivasi siswa dalam proses pembelajaran. Jakarta: Ghalia Indonesia.

Kridalaksana, H. (2001). Kamus linguistik. Jakarta: Gramedia Pustaka Utama.

Nurgiyantoro, B. (2013). Penilaian dalam pengajaran bahasa dan sastra. Yogyakarta: Gajah Mada.

Surharsimi, Suhardjono, Supardi. (2015). Penelitian tindakan kelas. Jakarta: Bumi Aksara.

Tarigan, H. G. (2008). Berbicara sebagai suatu keterampilan bahasa. Bandung: Angkasa. 